\title{
Economic development as a way to fight against poverty in a coastal society
}

\section{Pembangunan perekonomian sebagai upaya penanggulangan kemiskinan masyarakat desa pesisir}

\author{
Rukin \\ Universitas Teknologi Surabaya \\ Address: Jalan Balongsari Praja V No.1, Lontar, Sambikerep, Surabaya 60188 \\ E-mail: rukinspdmsi1975@gmail.com
}

\begin{abstract}
This research is based on the phenomenon of low construction in coastal village areas, primarily in relation to the economic development sector. This study was conducted in order to determine the low economic level of coastal rural communities and its abundant natural resources (SDA). The government has already issued a public policy related to economic empowerment and coastal zone management. However, the coastal village community's economy remains very low. The qualitative and phenomenological approach was used to obtain the findings about why society in coastal villages is economically low level. The main cause of the economic problem was the lack of ability of the public to capture the business opportunities that existed. In addition, the constant hereditary lifestyle of the coastal people is one of the triggers of their low economic power. There is a lack of distinct empowerment by the government in order to improve their economy. SDA has not been optimally empowering coastal areas by way of the village communities of the coast and there is a lack of village infrastructure. The concrete participation of the local government is expected in relation to the handling of economic empowerment. One solution that can be undertaken is the revamping of public policy related to the development of coastal villages. The completion of the installation program for paving and street lighting is also a priority. The development and empowerment of the economy should be done immediately. Another thing that can be done by the government is the optimisation of the religious and beach tourism there.
\end{abstract}

Keywords: development; economy; coastal society; poverty

\begin{abstract}
Abstrak
Penelitian ini didasari dari fenomena masih rendahnya pembangunan yang terjadi didaerah-daerah desa pesisir utamanya pembangunan dibidang perekonomian. Untuk itu penelitian ini dilakukan guna mengetahui rendahnya perekonomian masyarakat desa pesisir padahal sumber daya alam (SDA) pesisir sangat melimpah. Pemerintah sudah mengeluarkan kebijakan publik yang berhubungan dengan pemberdayan perekonomian serta pengelolaan wilayah pesisir, namun yang terjadi perekonomian masyarakat desa pesisir masih sangat rendah. Dengan menggunakan metode kualitatif dan pendekatan fenomenologi didapatkan temuan-temuan tentang rendahnya perekonomian masyarakat desa pesisir ini. Penyebab rendahnya perekonomian ini diantaranya masyarakat kurang dapat menangkap peluang bisnis yang ada, selain itu pola hidup masyarakat yang kurang tepat secara turun temurun juga menjadi pemicu rendahnya perekonomian mereka. Kurang adanya pemberdayaan yang jelas dari pemerintah guna meningkatkan perekonomian mereka. Belum diberdayakannya secara maksimal SDA wilayah pesisir ini oleh masyarakat desa pesisir serta kurangnya sarana-prasarana infrastruktur desa. Diharapkan adanya peran serta pemerintah secara kongret dalam penanganan serta pemberdayaan perekonomian mereka. Salah satu solusi yang daapat diambil adalah pembenahan kebijakan publik yang berhubungan dengan pembangunan desa pesisir, selain itu penyelesaian program pavingisasi dan penerangan jalan juga menjadi program prioritas. Pembinaan dan pemberdayaan perekonomian mereka harus segera dilakukan. Hal lain yang dapat dilakukan oleh pemerintah adalah optimalisasi wisata religi dan wisata pantai yang ada.
\end{abstract}

Kata kunci: pembangunan; perekonomian; masyarakat desa pesisir; kemiskinan

\section{Introduction}

Coastal villages and small islands are an inevitable reality of income inequality and economic development gaps compared to other areas of the mainland. Social and economic policy related to coastal society needs to be re-organised in order to embody Indonesian coastal community welfare, 
as well as to maintain resource sustainability, so that the social and economic activities in the coastal area can be accelerated in a sustainable way.

The management of marine and fishery resources requires comprehensive, integrated and targeted policies, considering that the region has unique problems, potentials and characteristics. The most important thing is to make marine activities and fisheries the mainstay sector focus of development, which is the need to change the development paradigm (Lasabuda 2013). The level of participation in relation to child development and educational issues is quite high. Social participation is quite high, but the participation rate in improving the family economy is very low (Saraswati 2014). Supporting the economic improvements requires cooperative institutions such as Koperasi. The main task of the Koperasi is to provide goods and services to meet the needs of its members. From this institution, the fishermen decided to join the cooperative (Indarti \& Wardana 2013) .

The fishermen communities have a high level of solidarity and a low level of religion. They also exhibit a lack of attention to health and hygiene. The lack of education and knowledge is primarily in the marine sectors, where there is less participation and a role for the community (Imron 2012). If we apply integrated coastal resource management for the boosting of coastal development, then coastal development can be both optimal and sustainable (Effendy 2009). For the development of cultural tourism required the cooperation between the government, private and local communities (Rukin 2015).

Rukin et al. (2018), explained the level of this coastal village community's economy is still relatively low due to the lack of coastal utilization of natural resources as well as possible. The coastal village communities less able to capture the business opportunities that exist due to the low level of their education and the lack of guidance from government. Lack of knowledge and skills with poverty such as a pair of causes and consequences. The one could be cause for others. That is what is experienced fishing communities. They are backward education so difficult to hack poverty, and because they are poor so it is difficult to move from underdevelopment education (Agussalim 2014). The development of rural agriculture, an approach is needed to help better agricultural extension and other rural development service institutions to meet the needs and demands of local communities (Agossou 2000).

Ambariyanto \& Deny (2013), with the help of various trainings, as well as other assistance the fishermen can get great results without getting to know the seasons. Apriliani (2014), the priority of all alternative programs in realizing Blue Economy is the community empowerment program in monitoring and controlling marine resources. Suggestions that can be conveyed to the effort to deal with Blue Economy is the guidance of economic group of coastal communities. Sara (2014), in the formulation, planning and management of integrated coastal areas cover the management of coastal and marine environment resources and services through a comprehensive assessment, plan goals and objectives, then plan and manage all utilization activities to achieve optimal and sustainable development.

Kusumastanto \& Satria (2014), explained characteristics of coastal villages 2030 is an independent village in terms of fulfilling the basic needs of its people namely food, energy, education and as well as a number of socio-cultural, economic and ecological characteristics. Community and participation have become popular in development discourse and practice, particularly in the global South and in relation to water resources management. Greater involvement of people in decisionmaking, implementation and evaluation of water management practices is expected to increase efficiency and equity in water projects (Sultana 2008)

Razali (2004), explained the national development of Indonesia must gives priority to seashore and ocean development program. It means, national development must pay attention to using of seashore and ocean resources and how to empower the seashore and ocean community, pass through seashore and ocean sector approach, by using community-based fishing system management is appropriate. By this policy, seashore and ocean resources can used to increase the community of seashore and ocean social welfare. Co-evolutionary engineering design for development' begins with a relationship 
among partners in the global village, informed by on-the-ground realities out of which culture/ environment/location-specific solutions emerge. This learning, iterative process among partners includes cooperation, local expertise, local resources and reliance on the global environment as a 'lab' for knowledge-sharing and open-source innovation (Murcott 2007).

Miraza (2009), explained the Coastal Community Economic Empowerment Program opens opportunities for coastal communities to facilitate access to capital. Masdjoeki (2012), participatory approaches that involve local communities and governments in natural resource management so that efforts can be made to improve community welfare by expanding employment opportunities in addition to management of marine resources based on optimum and sustainable use of resources. Based on the existing phenomenon, most of the coastal villagers work as fishermen, farmers and unskilled labourers. They still live in severe poverty. In order to free them from poverty and to improve the economy, there must be sustainable economic empowerment. The empowerment of a coastal society is inseparable from generic local wisdom. Therefore, the socio-cultural order of society must be the main foothold. The development and empowerment of these communities will not be accepted by the coastal communities without paying attention to the socio-cultural aspects of local communities.

Welfare is a mandate of the 1945 constitution and essentially the responsibility of the government, but until now, the government has not been able to benefit the people. This is due to the many problems in relation to the condition of the nation's economy post-reformation, 1998 until today. In fact, the government has been working on various ways to reduce poverty. This effort is to improve the welfare of the nation, although the results are still not perfect. Therefore, the economy is organised as a joint effort based on the principle of kinship. Meanwhile, the economy is built on economic democracy for the prosperity of all. Looking at the phenomenon that has occurred above, it is necessary to conduct an in-depth assessment of the problem: "The low economies of coastal society with abundant natural resources". This problem needs an appropriate solution so that the economy of the coastal village community can improve.

\section{Research Method}

In this research, we used the qualitative method supported by the phenomenological approach, Denzin \& Lincoln (2009). Meanwhile, to obtain accurate results, we conducted in-depth interviews with resource-knowledgeable individuals who understood about the issues being studied. The theory used as a reference is the theory of Merriam (2002). This research was conducted in Sawohan Village in the Buduran District of the Sidoarjo Regency, where some of the area of the village was located in a pond area which is difficult to reach by public transportation.

\section{Result and Discussion}

The economy and poverty are two links that are always connected. The low level of the economy of a society leads to high levels of poverty. It takes hard work continuously to overcome it. This cooperation should be carried out by the government, the public at large and if possible, from the private sector that is expected to synergise in this regard. The problem of poverty cannot be solved easily. This is because poverty is a multidimensional problem covering various aspects of life, not only the economic side but also the social and cultural elements.

The number of rural poor is caused by the lack of supporting infrastructure, as well as the problem of limited access of the residents to transportation, health and education facilities and the related infrastructure. The geographical conditions greatly affect their economic level.

\section{Poverty}

Bappenas (2004) defines poverty as a condition in which a person or a group of people, men and women, are unable to fulfil their basic right to maintain and develop a dignified life. The basic rights of the village community include the fulfilment of food access, health, education, employment, 
housing, access to clean water, land, natural resources and the environment, security from ill treatment or the threat of violence and the right to participate in a socio-political life, both for women and men. Chambers (1998) defines poverty as an integrated concept that has five dimensions, namely: poverty (poverty), powerlessness, vulnerability to emergency situations (state of emergency), dependency (dependence), and isolation both geographically and sociologically.

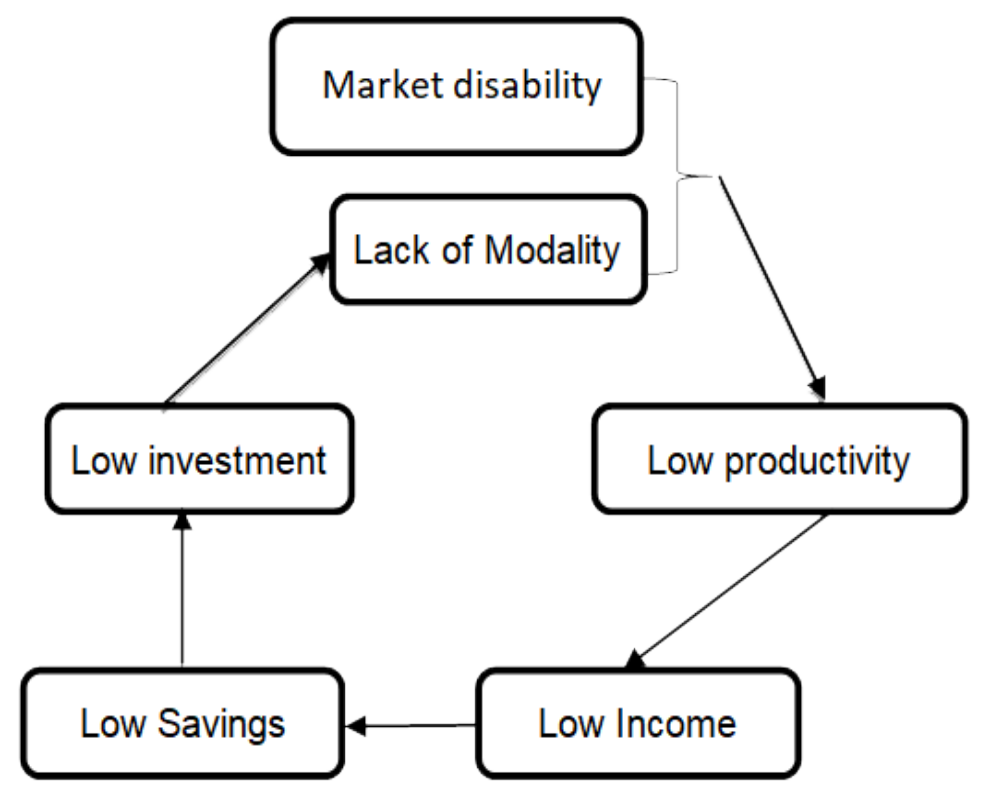

Figure 1.

Poverty cycle

Source: Nurkse 1953

\section{The poverty of fishermen}

According to Kusnadi (2002), the distinguishng factors causing the poverty of fishermen come in two groups: internal fishermen's poverty and external poverty. Internal fishermen's poverty includes 1) the limited human resource quality of the fishermen; 2) the limited capabilities of the venture capital to capture new technology; 3) employment relationships in fishing organisations that are often unfavourable to workers; 4) difficulty in diversifying fishing efforts; 5) high dependence on an occupation related to the sea; and 6) lifestyles that are considered wasteful, and less oriented to the future and long-term goals.

\section{Coastal society economic empowerment, poverty eradication and alleviation}

The strategy and alternative policy used to eradicate poverty in coastal areas can be done through giving the opportunity to access good education and health services. This is in addition to strengthening the executive and legislative commitment to good governance and pushing the economic development agenda towards reducing poverty as the main priority of the government. Pro-poor policies and programs need to be focused on the real sector of the economy and should adopt the paradigm to the poor. As one of the buffer regencies for Surabaya which has an industrial area and several huge warehouse systems, the Sidoarjo Regency has committed to increasing the economic level of society to eradicate poverty in the whole region. Poverty is one of main social problems that needs to be fixed. Synergistically and systematically, poverty reduction must be done so that all citizens are able to enjoy the results of development so they can have a dignified life. Therefore, the synergy of all stakeholders and interest groups, as well as the wider participation of the community, is necessary.

In fact, the government has not included society participation in every program to synchronise the program in accordance with the target desired. It is expected that in the future, the government should involve broad community participation so that the program can be on target, with community 
participation expected to be a control in the implementation of the program. From the existed phenomenon, natural resources are very abundant in coastal areas. The lack of empowerment in both the location and society optimally is the main cause. In order to increase the level of economy in coastal society, there is a high intensity of concern from every sector and decision-makers both public and private find it very necessary.

Meanwhile, to accelerate development in the Sidoarjo Regency in order to increase the level of economy for the people in coastal areas, in 2013, local government issued the Sidoarjo Regent's Regulation No. 57/2013 on the Detailed Plans of the Masterplan for the Strategic Coastal Area of the Sidoarjo Regency of Indonesia. However, the implementation of the policy has not been implemented in accordance with the expectations of the coastal villagers, BPS (2015).

From the field observations, the Sidoarjo coastal areas are a huge opportunity in terms of marine tourism development, both coastal tourism as well as religious tourism. The coastal area owned by Sidoarjo is very spacious and beautiful. Permisan Bay, along the coast of Sidoarjo, presents beautiful scenery. Kepentingan Beach is one such feature, in addition to Dewi Sekardadu sanctuary. If this condition is maximally empowered, then it will open up business opportunities for people on the coast. The coastal tourism sector has a very limited lack of management. Yet if it is really well managed, then the results will be felt by the community, especially in the coastal society in the region of Sidoarjo, Indonesia. With the right management of the tourism sectors, it will open up new jobs and employment around the area. Because of this problem, the society in coastal areas has started to develop an alternative way of business such as fish and shrimp livestock with tarpaulin media or making fish crackers and shrimp crackers with a minimum budget. Furthermore, some members of society have also opened up small stores and food stalls with limited capital. These efforts are to meet the need of their families. However, many of them are stuck in debt to meet their daily needs. This kind of lifestyle is not sustainable in the long-term. Due to this, their way of life will make them increasingly chained to prolonged poverty. The uncertain income and the debt system often results in the emergence of the exploitation of their children to fulfil their needs.

However, not all people in the coastal areas only rely on government assistance to survive. For instance, some of them have developed the simple technology of a fish pond around their home. This is due to their income uncertainty. Therefore, innovation is needed by way of opening up an alternate source of income from other businesses to meet the family needs. In order to do this, some people create a semi-permanent fish pond from tarpaulin on their front yard. The pools are for raising catfish and shrimp so that they can be used to support their economy.

From the field observation that has been done, we gained the conclusion that society in the coastal areas has not been able to capture new business opportunities from the sea and fish ponds, as both fish and shrimp farming and depending only on making crackers has no significant impact due to its small scale. This phenomenon is due to their lack of knowledge and a lack of coaching from the government. Comprehensive empowerment is needed in this case to support and increase the economic level of the coastal society. The participation both from the public and private sectors has to be synergised to boost the economic development in the coastal areas. In fact, a lack of participation and assistance from stakeholders still exists. The geography is the factor which makes these areas very hard to reach. It is clearly that the unwillingness from the local government to empower the coastal society is one of the other factors. This is especially in relation to empowering them to reach a better standard of living through economic development in the area. Meanwhile, there is also a lack of action from the government to boost the importance of home-based industry in order to lift up the economic level of society in coastal areas.

The low level of the economy is due to the lack of entrepreneurial coaching from the local government. The only assistance provided by the government is the Family Hope Program (FHP) (Program Keluarga Harapan), which is not followed by entrepreneurial coaching. The aim of the aid is to allow them to prosper and upgrade their economic level. 
The malfunction in the system occurred since the government is only giving out and providing shortterm assistance without offering a long term solution for the people. This lifestyle has become a habit for the coastal society, as there is an increasing amount of spending and standard of living only for a short period. The purchasing power will go up and they will spend it to fulfil their basic needs for a while without thinking of a long-term solution. This pattern of life is one of the biggest weaknesses for them.

From the field observation, the low level of education also affects the economic level. The coastal society is used to depending only on the sea as fishermen or from the pond that they have built. Education is not an important need in daily life. In fact, level of education is one of indicators of human resource quality. From this indicator, we can see if the society is considered to be poor or not, because most people with a low level of education has low productivity. Meanwhile, low productivity will affect their low income. Low income perkapita is the main feature of the poverty indicator.

The people in the coastal areas think that a higher level of education is not necessarily needed as they are fishermen, farmers, or conduct pond farming. These jobs are considered as cobble, which mainly use human strength rather than the brain, and experience rather than thinking. Thus, higher education will not necessarily affect their ability to work. Furthermore, there will emerge a new social problem; the low level of education will affect the way of thinking of their kids in terms of job searching. Children are considered a ladder and have the expectation of increasing their income. A low level of education will make them unqualified, so it will be difficult for them to get a job that is anything other than being a fishermen and farming in the pond. From this point of view, education for coastal communities is very influential in order to release them from the poverty cycle. This can be a poverty eradication tool.

Local culture and wisdom can strongly affect their economic level. The constant poverty of the coastal society is due to structural habits and the low living standard of the people. For instance, if they want to celebrate a special occasion, they will borrow money from people which are considered financially to be more stable. They will only pay back their debt at $50 \%$ of the total actual debt that they have borrowed for the sake of togetherness. It is a hereditary custom and is considered to be a state of harmony. This phenomenon makes their life be one of constant poverty, and because it is considered local wisdom, it is more difficult to get rid of. In addition, the most common job in these areas is that of a fishermen. However, these fishermen frequently borrow money from the fish collector as capital to start their business. In return, they expect that the collector will buy their catches and automatically deduct it from their debt.

However, the amount of the fish that they catch is uncertain on a daily basis. If the amount is sufficient, then they will use the rest of the money back home. But if the amount is not sufficient, they will need another debt to close the previous debt or else they have to ask for more. This vicious cycle will eventually make them trapped in an endless debt with the fish collector. The same thing occurred with the pond farmers. They use a loan to start and run their business, including seed purchasing, feeding as well as harvesting the fish. If they can harvest a sufficient amount, they can get additional revenue from it. Contrary to this, if the harvest doesn't meet the expected results, they will experience a loss. These farmers never think about the long-term impact of this business model. According to this phenomenon, there should be empowerment as well as a flexible loan that could benefit them. This solution would be sure to release them from an endless debt.

Most of the wives of the farmers are unskilled. After being observed, these women have a low level of education, and are unskilled, inexperienced and have a lack of knowledge especially from the local government regarding entrepreneurship activities. These women could manufacture processed foods which can be marketed and sold everywhere, but at this stage, they can't capture this business opportunity to increase their monthly income. This problem is a main concern that needs a serious attention. It is the absence of public awareness in the society or their laziness that means that these opportunities are never taken up by them. 
It is necessary to establish entrepreneurship from the government and private parties, and for the aforementioned parties to become their companion including up to the marketing process. Capital assistance with an easier payment system should be provided if possible. This effort is one solution offered to increase their economic level and living standards. However, the responsibilities have to be managed by groups, not individually, because there are so many cases where the financial aid as well as a loan from the government is largely non-refundable. To prevent this case occurring in the future, a communal system with a single person in charge who can manage and be responsible as the head is necessary. A single financial responsibility is considered safer for the long-term return of the debt. This is due to the difficulty of returns from an individual loan.

Aside from the problems above, there are still neglected problems in the coastal areas i.e. unorganised goat farms with a lack of attention and empowerment from the Animal Husbandry Department. There are nearly two thousand goats being raised in Sawohan village owned by about 36 people belonging to a goat breeder group called "Oro-Oro". These cages are located in the fishpond areas. In addition to breeders who belong to the group "Oro-Oro", there are many other individual breeders who are not included in this group. The large number of goat pens that are located in the fishpond area and around the village community shows that there are more than two thousand goats in the farm.

The owner of the goat pens and the farmers often follow local wisdom and heredity culture from their ancestors to let the goats stay out of the cages in the morning and to put them back in the afternoon. These farmers only rely on the grass around the area without any additional nutrition to make the goats healthier. The five monthly regular check-ups by the Animal Husbandry Department are not held routinely, as sometimes they come because the breeder group called them. The breeders have a goat farm group, but these groups are still regarded as being traditional. This group functions as a form of media communication without providing any governance upgrading the development of the farming business in a more advanced way.

If this activity could be managed professionally and in a modern way, the best result could be achieved which would increase their income and economic level. Composting goat droppings is one opportunity, because the goats can produce 2-3 droppings per day. If this opportunity can be managed well by the society, these areas could be a big goat farming centre.

Comprehensive efforts, coaching and empowerment from the local government to help, upgrade, manage and innovate the goat management business is needed for the farmers. Aside from this, the existence of communal management in terms of goat farming provides a market and marketing skills in a way that displays more advanced management. This new business model of farming can open up new chances as well as being an innovation and expansion such as that done by Aqiqah and Qurban. The farmers can do it in a group together with other villagers or an individual could be a goat supplier. This will open up new job opportunities for the coastal society.

In addition through the household industry sector, fisheries and animal husbandry, this area is very suitable for tourism development. By making Permisan Bay, the mangrove forest and its surroundings as well as the grave site of Dewi Sekardadu a good tourist destination, it is expected that the additional income for this coastal village community has increased, especially for the community of Kepentingan Sawohan.

There were many visitors who came from other areas visiting Dewi Sekardadu's grave site during the field observation. Especially on Sundays, weekends, and national holidays, there were many pilgrims, especially during the big festival days for Islam, such as before Ramadan and the month of Rabiul Awal. However, these two tourism opportunities have not been managed properly until now, and even the mangrove forest is less well maintained.

\section{The coastal society economic empowerment}

From the above findings, the government has provided assistance to the coastal society in order to improve the welfare around and within the area, but it has not yet met the desired target. The 
core problems faced by the community of cracker makers are due to the lack of participation and empowerment from the government in order to improve their economy. The existence of soft capital loans is important, but more importantly, an empowering and coaching program regarding loan utilisation should be held.

The lack of competence of the people to capture new business opportunities from fish and shrimp is one of the problems. The less marketable fish could be processed as another valuable food which has more value in terms of prices. However, the role of the Food Security Service and the Department of Cooperatives of SMEs and BPMPKB to empower and introduce this idea to society is important. The Department of Industry and Trade provides guidance to home-based businesses. The point is to provide the community with an understanding of the manufacture of processed seafood and fishponds such as fish balls, shrimp balls, tempura, and other foods that are worth selling and to not just focus on making crackers. It takes massive involvement from the government to provide guidance to the community to start new business opportunities in relation to coastal area commodities. For instance, the people can make fish or shrimp balls as well as drying fish as established by the Office of Food Security in order to penetrate the modern marketplace. Hence, to transform the business into a modern business, they need to be well-prepared and have good management as well as a marketing system. In the long run, the people expect to run and manage the business as a Village Owned Enterprise (BUMDes) that accommodates and sells the product produced.

Regarding the crackers and shrimp paste business pioneered by the community in the coastal area, the marketing system is still the core problem. BUMDes, in this regard, could make new breakthroughs by having a better marketing strategy. Cooperation with local supermarkets as well as bigger supermarkets is one of the solutions available. A well-targeted marketing system is believed to increase production. Thus, as production increases, new job opportunities will emerge, especially for local society in the coastal areas.

The more developed the business is that is managed by the people, the bigger the BUMDes. The more cash flow that there is into BUMDes, the bigger the capital received as well as the income percentage. Besides, the bigger the business, the bigger the opportunity for the society to become independent, thus making the village become a Processed Sea Product Centre. They will not only produce crackers and shrimp, but also produce highly competitive dry fish.

The synergy between empowerment, role, active participation from the government, stakeholder, as well as policy maker and the whole participation of local society. Beside, the participation from private sector towards the economic development of coastal society. This is one of the basic models in order for the coastal society to become bigger and to develop their business. Regarding the homebased industry and fishery field problems, comprehensive empowerment for the goat farmers has to be done intensively, involving engagement with the Department of Animal Husbandry and Animal Health. The government could provide superior seed from male goats. It is believed that the farms will become big, the livestock healthy and the results will certainly increase their income.

The marketing system, both individually and collectively, involves BUMDes with their comprehensive and innovative breakthrough in the marketing sector. The marketing includes Qurban and Aqiqah services, managed directly by BUMDes. At this point, job opportunities are increasing in the coastal areas. In addition, the goat farmers who have not joined the breeder group are expected to join soon in order to get the same service and knowledge in terms of farming goats. The increase in the income revenue of the society of the coastal area eventually will increase the economy in the area, thus they will be free from the shackles of poverty.

Marine tourism, coastal tourism and religious tourism could sustain the economic sector of the coastal society. Thus, by improving all three sectors, the economy of the coastal society is expected to increase. Marine tourism at Permisan Bay, as well as religious tourism at Dewi Sekardadu grave site, is expected to become a tourist destination. The repair and completion of the installation of 
paving and lighting in the centre of the farm area will ease the trips by motorcycle at night. Groups of tourists and pilgrims who use the bus or a private car can park their vehicle in public parking spaces. Thus, tourists can continue their tour using gojek to the next destination around the coastal areas. This new business opportunity could open up other kinds of job such as parking attendants and motorcycle taxi drivers. In addition, people can open stalls that peddle typical unique souvenirs of the coastal society or sell other foods.

Well-prepared and managed tourism destinations in Permisan Bay and at Dewi Sekardadu grave site could be initiated by the Tourism Department in the short-term. This strategy is expected to improve and impact on the economic level of society. In addition, additional income could come from Local Own Revenue (PAD) of the tourism sector. The government can cooperate with the private sector to objectify marine tourism as soon as possible. These activities could create new job opportunities as well as new business opportunities for the coastal society in general. This can't happen without active participation between the government, the private sector, and society itself.

To accelerate the management process of tourism, cooperation is inevitable between the third parties involved and the tourism investors. By opening up the tourism destination, it will also open up new job opportunities. By opening up new job opportunities, the economic level of coastal society will increase in accordance. Through this program, it is expected that the insight and knowledge of society will broaden.

Tourism management is a collective activity between the public and private sectors, the Tourism Ministry of Sidoarjo Regency and Local Government. The revenue system with a shared income is in accordance with their duties and responsibilities. In order to maintain the road system towards the tourism destination, local government should bear the responsibility of the maintenance system and the income sharing of its subsequent management. This system is considered to be more effective compared to the system managed by the private sectors.

Due to difficulties in communication and cellular telephone access, cooperation between the communication sources and the internet provider is needed. This factor is important and could be made to lure tourists to come to the destination. The government could manage and invite the providers to build a transmitting signal tower in this area. This is one of the attractions that could be used to lure tourists as well as the pilgrims.

\section{Conclusion}

From the analysis of the above, it can be concluded that the economic level of coastal society is still relatively low because of the lack of the utilisation of coastal resources optimally. This is because the coastal society is less able to grasp existing business opportunities due to the low level of education and a lack of guidance from the government.

The supporting system and infrastructure of coastal society is still very lacking. This will greatly hinder the development process of coastal society in relation to all aspects of economic development In order to solve these problems, both the government and the private sector are involved. The government should provide entrepreneurial guidance to coastal communities so that they will immediately seize available business opportunities without always relying on government assistance. The completion of the paving and lighting program has become the main priority to be completed by the government. If these two things are resolved, it will further facilitate the activities of the coastal village community.

Local government has immediately established a local state-owned enterprise (BUMD) as well as actively looking for new breakthroughs in the sales system of communities and farms. This is as all processed products made by the community should be easy to market. The optimisation of the religious tourism area of Dewi Sekardadu grave site, Permisan Bay beach and the Mangrove Forest tour in the village is expected to increase the standard of living and income of the coastal society. It will also increase the economy of the coastal communities. 


\section{References}

Agossou (2000) Village Participation in Rural Development. Royal Tropical Institute / World Bank. ISBN 9068321366.

Agussalim (2014) Pemberdayaan, meretas kemiskinan nelayan. http://bp3ambon-kkp.org/wpcontent/uploads/2014/03/Pemberdayaan-Meretas-Kemiskinan-Nelayan.pdf.

Ambariyanto \& Denny (2013) Kajian pengembangan desa pesisir tangguh di Kota Semarang. Riptek, 6 (II):29-38.

Apriliani (2014) Economics development analysis. Journal Universitas Negeri Semarang. ISSN 2252-6765.

Bappenas (2014) Rencana Pembangunan Jangja Menengah Nasional (RPJMN) 2015-2019. Kementrian Perencanaan Pembangunan Nasional/ Badan Perencanaan Pembangunan Nasional.

Bengen (1998) Pengelolaan Sumberdaya Pesisir dan Lautan Indonesia. Pusat Kajian Sumberdaya Pesisir dan Lautan Institut Pertanian Bogor.

BPS (2015) Statistik Daerah Kabupaten Sidoarjo 2015. Badan Pusat Statistik Kabupaten Sidoarjo Catalog Number: 1101002.3515.

BPS (2015) Sidoarjo dalam Angka 2015. Badan Pusat Statistik Kabupaten Sidoarjo Catalog Number: 1102.3515 .

Dean K (2008) A Comparative Study of Chinese Local Society in Historical Perspective: Lineage, Ritual, Economy and Material Culture in the Chinese Village. McGill University, Montreal.

Denzin \& Lincoln (2009) Handbook of Qualitative Research. Edisi Bahasa Indonesia. Pustaka Pelajar. Yogyakarta.

Effendy (2009) Pengeloaan sumberdaya pesisir. Jurnal Kelautan, 2 (1). ISSN: 1907-9931.

Haswell (1967) Economics of Development in Village India. The International Library of Sociology.

Indarti \& Wardana (2013) Metode pemberdayaan masyarakat pesisir melalui penguatan kelembagaan di wilayah pesisir Kota Semarang. BENEFIT Jurnal Manajemen dan Bisnis, 17 (1):75-88.

Imron A (2012) Strategi dan usaha peningkatan kesejahteraan hidup nelayan Tanggulsari Mangunharjo Tugu Semarang dalam menghadapi perubahan iklim. Riptek, 6 (I).

Kusnadi (2002) Konflik Sosial Nelayan, Kemiskinan dan Perebutan Sumberdaya Perikanan. Yogyakarta: LKiS.

Kusumastanto T \& Satria A (2014) Strategi pembangunan desa pesisir mandiri. https://www. researchgate.net/publication/266080890_Visi_Membangun_Desa_Pesisir_Mandiri_2030.

Lasabuda (2013) Pengelolaan sumberdaya perikanan dan kelautan. Jurnal Ilmiah Platax, I-2. ISSN: 2302-3589.

Mardjoeki (2012) Pemberdayaan masyarakat pesisir pantai utara daerah Kabupaten Cirebon. Jurnal Ekonomi, 1 (1). ISSN: 2302-7169

Miraza R (2009) Implementasi Program Pemberdayaan Ekonomi Masyarakat Pesisir (PEMP) di Kecamatan Tanjung Pura Kabupaten Langkat, Universitas Sumatera Utara.

Merriam SB (2002) Introduction to Qualitative Research. JOSEY-BASS, A Wiley Company - San Fransisco.

Murcott (2007) C0-evolutionary design for development: Influences shaping engineering disugn and implementation in Nepal Aung The Global Village. Journal of International Development J. Int. Dev. 19:123-144. www.interscience.wiley.com. DOI: 10.1002/jid.1353.

Razali (2004) Strategi pemberdayaan masyarakat pesisir dan laut. Jurnal Pemberdayaan Komunitas, 3 (2):61-68. Universitas Sumatera Utara. 
Rukin (2015) Pariwisata pesisir sebagai salah satu alternatif pemberdayaan perekonomian masyarakat desa pesisir. Jurnal Ilmiah Sosial \& Humaniora, 9 (1):36-46. Universitas Surabaya, 2015.

Rukin, Rahman B, Toha A, \& Gianawati ND (2018) Coastal rural community economic development as a poverty reduction efforts. The International Journal of Social Sciences and Humanities Invention, 5 (4):4627-4633. DOI: 10.18535/ijsshi/v5i4.12, ISSN: 2349-2031, 2018, THEIJSSHI.

Saraswati (2014) Peranan istri nelayan dalam menunjang kehidupan keluarga. Jurnal Fakultas Ilmu Sosial, Universitas Pendidikan Ganesha Singaraja.

Sara (2014) Pengelolaan Wilayah Pesisir. Gagasan Memelihara Aset Wilayah Pesisir dan Solusi Pembangunan Bangsa. Alfabeta Bandung.

Sultana F (2008) Community and Participation in Water Resources Management: Gendering and Naturing Development Debates from Bangladesh. Department of Geography, Maxwell School of Citizenship and Public Affairs, Syracuse University, Syracuse, NY 13244, USA.

Trisbiantoro (2013) Model pemberdayaan masyarakat kawasan pesisir Kecamatan Watulimo, Kabupaten Trenggalek. Jurnal Mitra Ekonomi dan Manajemen Bisnis, 4 (1):18-29. ISSN 2087-1090. 